\title{
Male Breast Cancer Clinical Features, Risk Factors, and Current Diagnostic and Therapeutic Approaches
}

\author{
Mojgan Haji Seyed Ebrahim Darkeh1, Edward Azavedo² \\ ${ }^{1}$ Karolinska Hospital, Stockholm, Sweden \\ ${ }^{2}$ Department of Diagnostic Radiology, Karolinska University Hospital, Stockholm, Sweden \\ Email: mojgan.haji-seyed-ebrahim-darkeh@karolinska.se, edward.azavedo@ki.se
}

Received 17 July 2014; revised 14 August 2014; accepted 2 September 2014

Copyright (C) 2014 by authors and Scientific Research Publishing Inc.

This work is licensed under the Creative Commons Attribution International License (CC BY). http://creativecommons.org/licenses/by/4.0/

(c) (i) Open Access

\begin{abstract}
Objective: To review presentation, diagnosis, treatment and prognosis of male breast cancer. Method: A systematic review of the English language literature between 1990 and 2013 was conducted to identify studies relevant to the objective. Searches were carried out on the database PubMed, by using the title term "male breast cancer". Results: The majority of male patients present with a painless, firm, subareolar lump. Experience of male breast imaging is good but limited. However, there is no definitive therapeutic algorithm. Men are often treated with mastectomy instead of breast conserving surgery and mostly tamoxifen is used as an adjuvant therapy. The most important prognostic factors are tumor size and lymph node status in the armpit. Conclusion: More increased awareness and further research are needed to improve the diagnosis and treatment of this disease.
\end{abstract}

\section{Keywords}

Breast Cancer, Male Breast Cancer, Treatment, Diagnosis, Prognosis

\section{Introduction}

Male breast cancer is a relatively rare disease, which accounts for less than $1 \%$ of all instances of cancer in men and about $1 \%$ of all breast cancer cases [1]-[7]. It accounts for less than $0.2 \%$ of all cancer related deaths among men [8]-[11]. Because of the rarity of the disease, most information about male breast cancer has been obtained from small, mono-centric, retrospective studies or through extrapolation from randomized prospective studies or from clinical experience of breast cancer in women [12]. But this enormous volume of data on female breast 
cancer may not be completely relevant to men, particularly with regard to differences concerning the hormonal environment for men and women, and also in terms of gender differences that may affect the cancer patient's condition, medical and/or psychosocial side effects from treatments, and survival priorities. Men with breast cancer have a higher occurrence of ductal histology [5]. Infiltrating ductal carcinoma (ICD) represents more than $90 \%$ of all MBC cases [1] [3] but in women, the frequency of ductal histology is $70 \%$ to $75 \%$ [5]. Tumour types such as infiltrating lobular carcinoma (ILC), medullary lesions, tubular or neuroendocrine tumours are very rare in the MBC cases [1] [3]. Oestrogen and progesterone steroid receptor expression is also higher in male breast cancer [5] [12].

\section{Method}

This study is a systematic review of the literature. The literature review was conducted in order to describe the current state of knowledge and to compile the scientific literature within the field of breast cancer in men. The study processes the scientific papers in a systematic manner, which consisted of both empirical studies of quantitative and qualitative design, and theoretical or meta-analytic and overview studies. All of them had a clear link to breast cancer in men. The search for scientific literature was conducted in the PubMed database by searching for the key words "male breast cancer" and some articles were also selected from bibliographies from other publications.

Articles that were included in this study met these criteria:

-Articles were published between 1990-01-01 and 2013-09-30, which were in English.

-Articles were about primary breast cancer in men.

-Articles touched heredity and genetic aspects, clinical features, clinical histopathology, diagnosis and diagnostic methods (mammography, ultrasound, fine needle aspiration biopsy/core needle biopsy and sentinel lymph node biopsy), treatment (surgery, radiotherapy, hormone therapy and chemotherapy), prognosis (prognostic factors and survival), and psychosocial aspects.

-Articles made a clear comparison of breast cancer in men and breast cancer in women.

Articles were excluded if one or more of the following criteria were matched:

-Articles that were case studies or studies with less than 10 patients (with the exception of case studies of unknown/rare genetic factors to MBC or articles with qualitative approach and in-depth interviews).

-Articles that affected other aspects of MBC disease including local epidemiological aspects and demographic patterns, studies of environmental risk factors or the effects of various drugs and medications or relationship between MBC and races, research into the mechanisms of MBC tumors in cell level and in molecular subgroups or if a special or rare MBC tumor, etc.

-Articles that were studies of a certain group of people e.g. breast cancer in transsexual men or in HIV-infected men or among Jews.

-Articles that were about MBC metastasis.

-Articles that were irrelevant e.g. studies of gynecomastia or causes of death among a profession, etc.

Of the total of 812 articles, some were excluded. These included 11 papers on local demographic studies or about demographic patterns, 45 studies of environmental risk factors, drug or medication effects and the relationship between race and MBC, 90 studies on the mechanisms at cellular level, chromosome studies, DNA analysis and treatment mechanisms, 25 studies on rare types of MBC tumours, 111 case studies or studies with less than 10 patients, 53 studies whose abstract was missing in the database, 52 studies that were not in English, 4 studies on MBC in a particular group of people, 15 studies on metastases, metastasis sites or about secondary breast cancer, and finally, 101 studies that did not deal with MBC.

Due to the extensive information about MBC disease divided the study into two parts. The first part deals with the clinical features, diagnosis, treatment and prognosis aspects of $\mathrm{MBC}$ disease and the other part on genetic, histopathology, and psychosocial aspects of MBC and also comparison between MBC and FBC.

\section{Results and Discussion}

\subsection{Clinical Features}

MBC patients are usually in their sixties at presentation, but in the Middle East, China and South Asia and also in Africa, they are more often in their fifties (Figure 1). Symptom duration before diagnosis has decreased [13] [10], but there are large geographical differences i.e. less than eight months in western countries [14]-[16] and at 


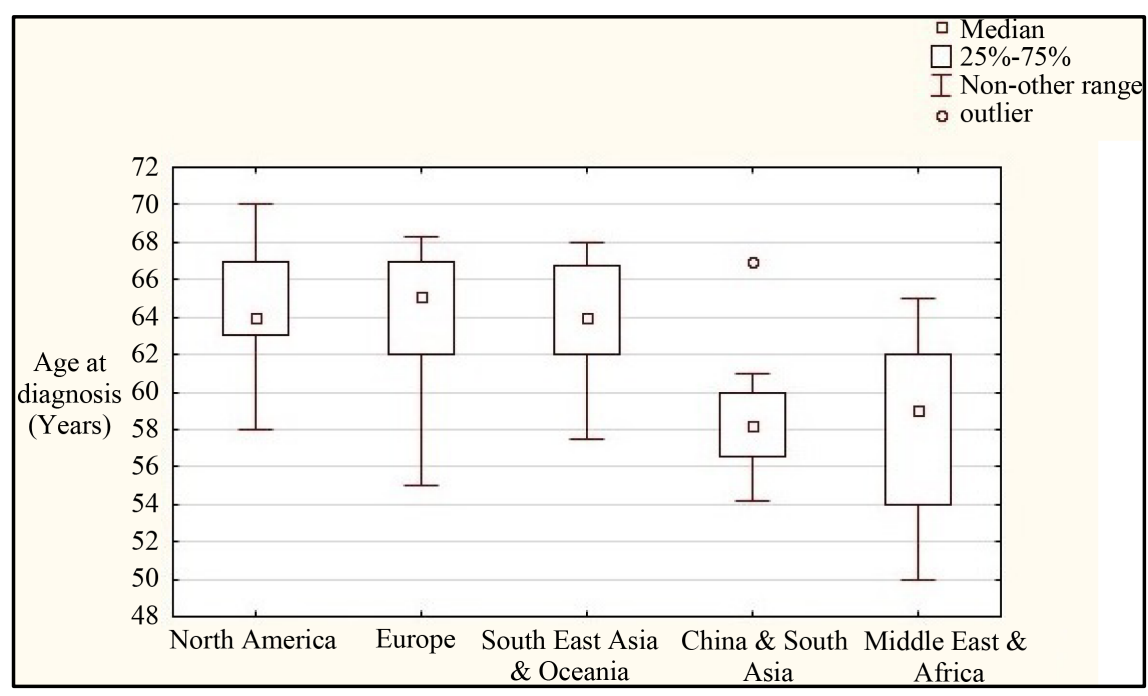

Figure 1. The correlation chart between median age at MBC diagnosis and parts of the world. North American clinical series of MBC patients: 3 Canadian +14 American, European studies om MBC patients: 2 British +3 German +1 Finnish +1 Swiss +1 French +1 Austrian +2 Spanish +1 Portuguese +2 Italian +1 Croatian +7 Turkish, South-east Asian clinical series of MBC patients: 4 Japanese +1 from Singapore +1 Korean +1 Malaysian +2 Australian, studies about MBC patients from China \& South Asia: 5 Chinese +4 Indian +3 Pakistani and studies about MBC patients from the Middle East \& Africa: 1 Iranian +1 Kuwaiti +1 Lebanese +2 Moroccan +1 Libyan +1 Egyptian +6 Nigerian +1 Tanzanian +1 West African.

least one year in Asia and in Africa [17] [18]. Rarity and hence a low index of suspected cases by both patients and their doctors are important factors for long duration of symptoms before diagnosis [19]-[21]. A painless but noticeable solid lump under the areola of the nipple is the most frequent symptom of MBC [4] [14]-[17] [22]-[29] [30]-[37] which may, in the intermediate stage, be painful to the touch and accompanied by clinical gynecomastia [16] [31] [38] with nipple retraction [6] [15] [16] [38]-[40] At the later stage, spontaneous pain with tenderness appears [6] [16] or with bloody nipple discharge [6] [16] [37] [38] [40] or with watery nipple discharge [14].

In the absence of other clinical signs, the presence of nipple discharge may be an indicator of a non-invasive disease, and early identification of this symptom is therefore important [41] [42]. The primary tumour may be of varying size between 1.8 and $3.5 \mathrm{~cm}$ [6] [25] [27] [40] but older patients have larger tumours in more advanced stages at diagnosis, compared with younger patients [43]. Carcinoma in situ (CIS, stage 0 ) occurs in less than $10 \%$ of MBC cases. Tumours $\leq 2 \mathrm{~cm}$ (stage 1) have been reported between $22 \%$ and $35 \%$. Tumours between 2 and 5 cm (stage 2) have been reported from $27 \%$ to $41 \%$. It has also been reported that up to $27 \%$ of male breast tumours are more than $5 \mathrm{~cm}$ (stage 3) or any size growing into the chest wall or skin (stage 4) [1].

The Male breast tumours are more often located centrally [6], with skin and muscle disorders [6] [38] and with enlarged lymph nodes in the armpit [6] [16] which are clinically detected in nearly half of the patients at primary diagnosis [14]. In 33\% - 46\% of the cases, four or more lymph nodes are involved [1]. Because of the dominant central position and the anatomical proximity, nipple involvement occurs at an early stage [19]. Bilateral forms of male breast cancer are much rarer compared to unilateral forms of cancer, and occur in less than $2 \%$ of MBC cases [14].

\subsection{Risk Factors}

\subsubsection{Genetic Factors}

A family history of breast cancer, in both men and women, is certainly a risk factor [19]. A family history of breast cancer confers a relative risk of 2.5 [3], 20\% of men with breast cancer have a first-degree relative the disease [19]. Genetic predisposing factors include abnormalities of both somatic and sex chromosomes [13]. Between $4 \%$ and $40 \%$ of male breast cancer are thought to result from autosomal dominant inheritance, particu- 
larly BRCA 1 and BRCA 2 mutations [3]. The mutation of the BRCA 2 appears to be risk factor for breast cancer in men more important than BRCA 1 [3] [13]. Between 3\% and 7\% of men with MBC, have the sex chromosome genotype of 47, XXY (Klinefelter's syndrome) with testicular dysgenesis, gynecomastia, low testosterone concentrations, and increased gonadotrophins [3]. These men may have up to a 50-fold increased risk of MBC [3] [12].

\subsubsection{Acquired Aetiological Factors}

Hormonal imbalance between oestrogen and testosterone has been suggested as a possible mechanism of MBC [1] [13] [19], which may occur endogenously due to testicular diseases or infertility or cirrhosis of the liver or by increased peripheral aromatisation of androgens [3] [12]. Endemic infectious diseases causing liver damage, leading to hyper-oestrogenism maybe explain the substantially higher proportion of MBC cases in some countries in Africa [19]. Exposure of the breast to ionising irradiation increase risk of cancer in women, which may be similar in men if they exposed to therapeutic or diagnostic radiation [3]. Chronic heat exposures or electromagnetic fields, which are supposed to suppress testicular function, maybe increase risk of MBC [13] [19]. Increasing age and obesity can also increase the risk of MBC, possibly because of the changed hormonal levels in the body [12].

\subsection{Diagnosis}

In order to obtain a better understanding of the male breast, it is essential to develop a differential diagnosis for male patients with breast problems [44]. Breast enlargement (gynecomastia) in men is a common condition with increasing age [34] [45], which is the most common breast disease in men [33] [44]-[48] and the most common mammographic finding [45] [49] and the main problem regarding the differentiation from breast cancer [34] [49]-[51], Breast enlargement may be caused by reduced testicular function in older males, leading to a reduction in testosterone but with continued normal oestradiol [33]. Breast cancer is a rare cause of breast enlargement [52]. Patients with gynecomastia are more likely to have pain and tenderness on clinical examina- tion [34]. Besides gynecomastia, radiographic examination of male breasts is also performed to evaluate other clinical abnormalities such as breast tenderness, an apparent mass in the breast, and nipple or skin changes, which in most cases are benign and malignancy is less frequent [53]-[55]. However, breast cancer in men is considered separately when evaluating a lump in the breast, even though various benign causes are more common [56]. MBC must be excluded in patients with unilateral breast mass, particularly in patients presenting with painless mass [34]. Breast cancer in men is usually suspected in connection with clinical examination [57] [58]. Clues to the diagnosis are provided by a history of cancer or a family history of breast cancer [34]. The patient's medical history may therefore identify important suspicions about malignancy or about benign diseases [56]. But the differentiation between benign and malignant mass in the male breast is critical and can cause anxiety in patients and lead to unnecessary procedures, which should be avoided [55]. Mammography seems unnecessary in most cases and should not be used as a routine imaging of the male breast. One should also consider only imaging the clinically suspected cases in order to avoid unnecessary imaging, especially in younger patients [58]. Since the male breast can be affected by a wide range of different diseases, some of which have characteristic radiological appearances which can be correlated with their pathological diagnosis [48] [59], mammography and ultrasound should be performed along with clinical examination in the evaluation of the male breast [48]. Mammographically, the male breast is characterized by a solid mass under the areola with separation from the nipple and with irregular edges [33] [39] which on ultrasound usually appears as a hypoechoic area [60] whose edges are angled or with micro-channels and points on the surface [61]. The appearance of a complex cystic mass in a male breast with ultrasound suggests possible malignancy, which requires a biopsy [62]. Micro-calcifications are uncommon [37] [48] [57] [59] but in case of any presentation, they tend to be large, round and scattered [33] [59] [63] Clinical examination is as effective as mammography in order to differentiate the benign from the malignant disease changes, and both of these diagnosis modalities have been reported with high levels of accuracy for the identification of malignancy [56], but the male breast is not easily examined with mammography because of its limited volume [60]. On the other hand, ultrasonic images of cancer tumours are not easily distinguished from benign lesions [54]. Ultrasound is very effective for the detection of isolated lesions [60] and it is a natural complement to the diagnostic work with clinical examination and mammography [53] [60]. Ultrasound has an established role as a biopsy guide for both female and male breasts [60] [62]. Correct identification of pathological 
male breast lesions using ultrasound is necessary in order to establish appropriate measures and diagnostic recommendations and to avoid unnecessary biopsies [53]. For example, ultrasound is important for demonstrating axillary lymphadenopathy [39] [55] [64] [65]. Mammography is undoubtedly superior to ultrasound for the identification and characterization of micro-calci-fications, but these are quite rare in male breast cases [60]. Several studies show that mammography has both high sensitivity and high specificity (Table 1), but there is conflicting information about the sensitivity and specificity regarding comparisons between mammography and ultrasound. For example, in a study by Muñoz Carrasco et al. (2013) [43], mammography had higher sensitivity, and in a study by Patterson et al. (2006) [66], mammography has higher specificity compared to ultrasound for breast cancer diagnosis in men. But on the other hand, Taylor et al. (2013) [67] reported in their study that ultrasound has higher sensitivity than mammography, and another study by Adibelli et al. (2009) [45] found that the sensitivity, specificity and validity of ultrasound is not only satisfactory, but is also superior to mammography. Morrogh \& King (2009) [68] have also reported that ultrasound, with 100\% sensitivity and 100\% specificity, is superior to mammography. But several studies have shown that both techniques with a negative predictive value (NPV) close to $100 \%$ make it possible to avoid a large number of unnecessary surgical interventions in men [42] [66] [50]. Since experience with male breast mammography is limited, with a high rate of false positive results due to gynecomastia and cysts [69], biopsy biopsy, in order to allow a definitive diagnosis in most breast cancer cases in men [57] [70]. Fine needle aspiration biopsy (FNA) of the male breast has been studied in more depth, as demonstrated with high sensitivity and high specificity, and with almost $100 \%$ PPV or positive predictive value for the diagnosis of malignancy [40] [69] [71]-[76]. FNA biopsy allows accurate diagnosis in many medical changes that occur in the male breast. But this technique is less helpful when it comes to male patients with DCIS, especially in lesions that are cystic, such as papillary DCIS, which has been described as having a strong cystic component [62]. Core needle biopsy or fine needle aspiration biopsy should be used more often, because these procedures can help to avoid unnecessary surgery and may help in the planning of any surgeries for cancer cases [77]. The decision on a biopsy should be taken on the basis of clinical and mammographic findings, together with the medical history [54].

\subsection{Surgical Treatment}

Surgery as a form of therapy is generally a key part of the treatment of breast cancer [78] [79] and is a "gold standard" for MBC treatment [80] [81]. Mastectomy is usually the primary treatment for early breast cancer in men [82]. Historically, radical mastectomy has been the most popular surgical option based on the logic that male breast tumours tend to be in the vicinity of the large breast muscle and are usually detected at a more advanced stage [14]. Surgical treatment has become less aggressive in recent years, from radical mastectomy to modified radical mastectomy and total mastectomy [78] [83] [84], since radical mastectomy involves high risks of post-operative complications [78], and because several retrospective studies have shown that there is no difference between these surgical procedures with regard to local cancer recurrence and/or cancer survival [14] [15] [36] [84]-[87]. Today, modified radical mastectomy is a standard treatment for MBC treatment [78] [79] [88] and the majority of patients undergo modified radical mastectomy [78] [89]-[91], except for MBC patients with

Table 1. Sensitivity and/or specificity of mammographic diagnosis of MBC.

\begin{tabular}{|c|c|c|c|}
\hline Study (year) & Purpose & Sensitivity (\%) & Specificity (\%) \\
\hline Muñoz Carrasco et al. (2013) [42] & $\begin{array}{l}\text { Evaluation of mammography and ultrasound regarding men with } \\
\text { nipple discharge }\end{array}$ & 100 & 100 \\
\hline Taylor et al. (2013) [67] & $\begin{array}{l}\text { Evaluation of mammography and ultrasound and clinical } \\
\text { examination in order to establish new proposals for age-specific } \\
\text { guidelines for imaging of the male breast }\end{array}$ & 92 & 90 \\
\hline Patterson et al. (2006) [66] & $\begin{array}{l}\text { Evaluation of mammography and ultrasound in the diagnosis of } \\
\text { benign and malignant breast problems }\end{array}$ & 100 & 90 \\
\hline Adibeli et al. (2009) [45] & $\begin{array}{l}\text { Evaluate the diagnostic validity of mammography and ultrasound } \\
\text { regarding male breast diseases and provide a diagnostic record }\end{array}$ & 69 & 87 \\
\hline Stewart et al. (1997) [63] & Evaluation of radiological imaging regarding the male breast & 92 & 90 \\
\hline Evans et al. (2001) [50] & $\begin{array}{l}\text { Evaluation of the validity of mammography regarding male breast } \\
\text { diseases }\end{array}$ & 92 & 90 \\
\hline
\end{tabular}


tumour spread in the thoracic muscle [92]. Modified radical mastectomy, together with radical mastectomy, is now the most common surgical treatment of MBC, which is over $70 \%$ of the total surgical MBC treatments [10] [14] [38] [87] [93] [94]. It is believed that the cosmetic result of mastectomy is not a problem for men, but lumpectomy or breast-conserving surgery may be preferred for certain MBC patients, in part because of a significantly lower post-operative morbidity [95]. Lumpectomy is performed in a small but growing percentage of MBC patients [96], but this treatment procedure is usually not considered to be feasible for men, even at an early stage of the disease, because of the paucity of breast tissue in males [12] [83] [92] and the central location of the majority of male breast tumours [92]. Also in conjunction with mastectomy, a few studies have shown that lumpectomy is correlated with poorer local control of the disease [83] [87], but nevertheless, this surgical technique can be used in patients with poor general state of health [12] [61]. Axillary lymph node dissection (ALND) is also an important part of the surgical treatment of men with invasive breast cancer [1] [3] [13] [97] [98], but because of its complications, sentinel lymph node biopsy (SLNB) will be used in future to identify node metastases with a high level of accuracy [1] [3] [97] in men with clinically node-negative breast cancer, which has produced good results with high sensitivity and/or specificity in several small retrospective studies [99]-[107]. This technique should be used in patients with primary tumours of less than $2.5 \mathrm{~cm}$ in size, without clinically suspected lymph node involvement [1] [2].

\subsection{Radiotherapy}

Post-operative radiotherapy reduces the risk of local cancer recurrence and improves long-term survival rates in women [3]. The criteria for its use for MBC treatment is generally extrapolated from data about FBC treatment [108] [109]. Standardized indications for irradiation of the thorax and lymph node in the armpit regarding female breast cancer include: large tumour and its spread to the nearby skin, to the areola or to the large chest muscle, and lymph node involvement in the armpit [3], with a radiation dose of $50 \mathrm{~Gy}$ divided into 25 fractions [3] [19]. Radiation therapy should be used for tumours that are larger than one centimetre in diameter or with more than one metastatic lymph node [1] [2] [12] or where there is a high risk of chest wall metastasis [110]. Adjuvant loco-regional irradiation should be used more extensively for male breast cancer, compared with female breast cancer, due to the higher proportion of locally advanced disease and in particular, the central location of male breast tumours and with greater likelihood of lymph node involvement in the armpit [2] [11] [12] [87] [111]-[114]. Men who undergo breast-conserving surgery should also be treated with post-operative radiation [70], because lumpectomy results in unacceptably high rates of local cancer recurrence, which can be reduced with the combination of local radiation therapy [87]. Radiation therapy is also recommended because of the fact that rudimentary breast tissue in MBC patients complicates tumour margins in the operation [115] and there is also a clear indication for radiation therapy when it is impossible to surgically remove the entire tumour from the armpit [116]. There is limited data regarding the need for radiation therapy after surgery [92] [12]. The use of radiation therapy in men with breast cancer has varied greatly over the past few years and has been very irregular. A careful evaluation is very difficult, therefore, because this treatment has been used after several different types of surgical treatments and also with different radiation techniques [1].

Adjuvant radiation therapy is considered to reduce the risk of local cancer recurrence associated with large tumours with lymph node and muscle involvement [61]. There are a few retrospective studies showing that post-operative radiotherapy in men can improve local control of the disease [10] [16] [78] [87] [117]-[120], but does not affect long-term cancer survival [5] [10] [15] [38] [87] [116] [117] [121] [122]. Historically, no survival advantage has been observed for the use of adjuvant radiation therapy for male breast cancer cases [91]. Post-operative radiation is routinely used in all stages of male breast cancer, but the risk of local cancer recurrence is small, especially in the early stages, and it is therefore better to use the same indications for post-operative radiation as apply for female breast cancer [123]. Radiation therapy after surgery is correlated with longer survival in men with breast cancer at disease stage III, but men with breast cancer at lower stages of the disease do not appear to benefit from radiation therapy [124]. Due to the fact that the most common location for local cancer recurrence in MBC patients is on the chest and above the clavicle, this should be taken into account when planning adjuvant radiotherapy [19]. Because MBC patients are also generally older than FBC patients, they are more likely to have cardiovascular problems and/or lung problems, and more sophisticated radiation therapy techniques must therefore be used to avoid unnecessary exposure of the heart and lungs [3]. 


\subsection{Hormone Treatment}

Because of the high sensitivity to oestrogen in male breast tumours, a large proportion of MBC patients have a good response to hormonal treatment [1] [13] [41] [79] [125]. Historically, orchiectomy, adrenalectomy and hypophysectomy have also been useful surgical methods for the treatment of male breast tumours [126] by altering the hormonal state of the male body [127], but today Tamoxifen is accepted as a standard adjuvant hormonal therapy for hormone-sensitive breast cancer [13] [92] [128], which has been shown to produce results comparable with orchiectomy [129] and with high levels of patient acceptance [7]. Several retrospective studies have shown good results with adjuvant Tamoxifen, resulting in improved five-year overall survival and/or fiveyear disease-free survival [78] [83] [94] [130] [131], but there are a few retrospective studies questioning Tamoxifen treatment of MBC [10] [132]-[134]. The relationship between oestrogen positivity and survival with Tamoxifen is less clear among men compared with women, because these studies include few patients and are often without a clear difference in survival outcome in terms of disease-specific or overall mortality, and with much shorter duration of Tamoxifen treatment, i.e., a 5-year optimal duration of Tamoxifen has not been studied in men [1] and there is a major need to address the issue of Tamoxifen compliance in this patient group [135]. On the other hand, male patients experience more side effects from Tamoxifen, such as weight gain, sexual dysfunction, nausea, depression and hot flushes [136]-[138], which may affect their compliance with the prescribed treatment [138] [139].

Tamoxifen is still the first treatment option for men with hormone-receptor positive breast tumours. But there are also other anti-endocrine and endocrine therapies that can be applied, such as aromatase inhibitors, androgens, anti-androgens and corticosteroids [31] [79] [140], but their use is dependent on the clinical response or cancer recurrence [31] [79] [140]. It was hoped that aromatase inhibitors will be useful in the treatment of MBC patients with metastases [141] [142], but ongoing case studies have unfortunately produced poor results [143]. Because the hormonal environment in male patients is different from that in female patients, the role of aromatase inhibitors is not clear in male patients [144]. A recent German study by Eggemann et al. (2013) [145] compared the effect of adjuvant Tamoxifen treatment aromatase inhibitor therapy on survival in men with hormone-sensitive breast cancer. 207 MBC patients had received Tamoxifen and the other $(n=50)$ aromatase inhibitors. 37 patients (18\%) treated with Tamoxifen and 16 patients (32\%) with aromatase inhibitor died during the follow-up period of 42 months. After adjusting for patient age, tumour size, lymph node status and tumour grade, it has been shown that patients treated with aromatase inhibitors had 50\% higher risk of death compared with patients treated with Tamoxifen (HR $=1.55$, 95\% CI: $1.13-2.13$; $\mathrm{p}=0.007)$. This means that overall survival was significantly better after Tamoxifen treatment compared to aromatase inhibitors. But more research is needed to evaluate the role of aromatase inhibitors for the treatment of MBC. Moreover, due to the biological differences between men and women, it is probably not wise to advocate the use of aromatase inhibitors as the only drug for the treatment of MBC [146].

\subsection{Chemotherapy}

Adjuvant chemotherapy in men with breast cancer is less established. However, the limited data shows good resultants [3] [12] [147], especially regarding high-risk subgroups and possibly younger patients [1].

Systemic treatment with cytostatics should be administered to male patients at stage II or greater [128] and to patients who are either hormone receptor-negative or resistant to various available hormone treatments [1] [61], [84] [148] [149], to patients with a significantly higher risk of relapse [12] or to patients with a tumour size above $1 \mathrm{~cm}$ or with positive node lymph status [110]. In clinical practice, chemotherapy is routinely recommended for male patients with positive lymph node status in the armpit [150]. But at the time of diagnosis, a large proportion of male patients are older and it is therefore very likely that there will be medical contraindications to receiving this treatment [88]. Surgery, radiation therapy and hormone therapy are used to the same extent in both elderly and younger patients, but older patients are less likely to receive adjuvant chemotherapy [43]. Several retrospective studies have evaluated adjuvant systemic chemotherapy in male breast cancer [10] [83] [94] [98] [128] [151]. Two of them have confirmed significantly improved survival [98] [151] and the third showed significantly reduced risk of recurrence [128] in male patients who received this systemic treatment.

The retrospective study by Izquierdo et al. (1994) [128] for the evaluation of adjuvant therapy (chemotherapy, hormone therapy or both) reported better disease-free survival for 17 patients who received adjuvant therapy, compared to 21 patients who had not received any form of adjuvant therapy ( $72 \%$ vs. $47 \%$ ). Furthermore, the retrospective study by Giordano et al. (2005) [94] showed that 51 patients, including 66\% with positive lymph 
node status, were treated with Tamoxifen, chemotherapy or both. Patients who received adjuvant systemic treatment had $43 \%$ lower risk of death, compared with patients who received no form of adjuvant therapy. During tumour progression in male breasts, a combined hormonal and cytostatics treatment can be used with considerably good results [152]. However, these reports should be interpreted with caution, given the small populations, limited follow-up times, and the inconsistencies in the stage of the disease and in studying the adjuvant treatment modalities [150]. With regard to adjuvant chemotherapy, MBC is probably an under-treated disease [147]. For example, an American study by Scott-Conner et al. (1999) [90] has shown that after adjustment for age and cancer stage, $27 \%$ of male patients treated with adjuvant chemotherapy, compared with $41 \%$ of women with the same disease. Decisions about adjuvant chemotherapy for MBC patients can be made by assessing the drawbacks and benefits in the same way as for FBC patients [3] [13] [147] [151] [153]. But the approach to this decision should take account of the experiences from treatment of post-menopausal women, rather than pre-meno-pausal women with early breast cancer [150] because male breast cancer behaves in many respects like post-menopausal breast cancer [27]. We also need further investigation of the role of adjuvant chemotherapy in the treatment of male breast cancer patients and the determination of optimal chemotherapy in the treatment of the disease with metastases [154].

\subsection{Prognosis}

\subsubsection{Survival of Male Patients with Breast Cancer}

The number of studies that have examined the survival rate of male breast cancer patients is quite small compared to the population-based studies on female breast cancer, and most studies on men with breast cancer have focused on overall survival, with the exception of a few recent studies that report disease-free survival [57]. Some studies show that other primary cancers, especially melanoma, prostate cancer and gastric and colon cancer, affects one in ten men with breast cancer during follow-up [155]-[157] and many men with breast cancer also have various cardiovascular, neurological and respiratory diseases [1] [3] [112] [158] and male breast cancer patients are more likely to die of other causes than female breast cancer patients [84]. This is important in order to better understand the differences between overall survival and disease-free survival [1]. In these retrospective series, as shown in Table 2, it is sometimes seen that the 5-year disease-free survival rate is larger than the 5-year overall survival rate, for example in the studies by Cutuli et al. (1995) [87] (74\% vs. 65\%), Donegan et al. (1998) [10] (66\% vs. 51\%), Selcukbiricik et al. (2013) [93] (72\% vs. 66\%) and Müller et al. (2012) [159] ( $79 \%$ vs. $66 \%$ ), which is due to the fact that some of the patients in these retrospective series, die during the follow-up period due to other primary cancers, or from other related diseases or from various complications and unknown causes [1]. "Disease-specific survival" is therefore a more suitable marker for studying the MBC prognosis, compared to "overall survival" [10] [87] [90] [158] [160]-[163]. In general, disease-specific survival is $10 \%$ higher than overall survival in MBC patients [115] [164]. The 5-year overall survival rate in male breast cancer patients varies greatly in different studies, with a range from $7 \%$ to $92 \%$. In retrospective series from western countries, the 5-year overall survival rate was reported with a range between $43 \%$ and $85 \%$, which in the older series is often below $70 \%$, but in the newer series over $70 \%$. These figures for Asian series are from $27 \%$ to $92 \%$ and for African series they are between $7 \%$ and $61 \%$. The 10 -year survival rate is from $24 \%$ to $60 \%$ and the five-year disease-free survival rate is from $41 \%$ to $79 \%$ in Western series. In Asian series, the 10 -year survival rate is from $28 \%$ to $77 \%$, and the 5 -year disease-free survival rate is between $46 \%$ and $92 \%$ (Table 2). These differences are partly explained by variations in study periods, the patients' co-morbidity and health care standards and quality of healthcare in the country where the study is conducted. These large ranges are also probably related to differences associated with cancer stages at diagnosis and treatment guidelines [57].

\subsubsection{Prognostic Factors}

Breast cancer has similar prognostic factors and behaviour in men and women [12] [61] [80] [88]. Survival in men is significantly associated with: 1) The degree of histological differentiation [15] [81] [134] [165]-[168], which means that a higher degree of differentiation of the tumour is associated with a poorer prognosis; 2) Clinical cancer stage [40] [87] [167]-[169] i.e. tumours at higher stages produce a worse prognosis; 3) The hormone receptor status [10] [82] [125] [170] [171], which means that tumours with ER+ and/or PgR+ have a better prognosis; 4) The tumour size [31] [38] [43] [98] [115] [134] [159] [167] [170] [172]-[174], which means that larger tumours are correlated with shorter 5-year survival rates (Table 3); 5) The most documented factor i.e. 
Table 2. Survival rate (\%) in MBC patients in different studies.

\begin{tabular}{|c|c|c|c|c|c|c|}
\hline Study (year) & Country & $\begin{array}{c}\text { Number of } \\
\text { patients }\end{array}$ & Diagnosis-period & $\begin{array}{c}\text { 5-year overall } \\
\text { survival rate (\%) }\end{array}$ & $\begin{array}{c}10 \text {-year overall } \\
\text { survival rate }(\%)\end{array}$ & $\begin{array}{c}\text { 5-year disease free } \\
\text { survival rate (\%) }\end{array}$ \\
\hline Borgen et al. (1992) [14] & USA & 104 & $1975-1990$ & 85 & & 68 \\
\hline El-Tamer et al. (2004) [84] & USA & 53 & 1980-1998 & 77 & 56 & \\
\hline Gough et al. (1993) [36] & USA & 124 & $1933-1983$ & 57 & 31 & \\
\hline Donegan et al. (1998) [10] & USA & 215 & 1953-1995 & 51 & 24 & 66 \\
\hline Williams et al. (1996) [51] & USA & 17 & 1959-1990 & 47 & & 41 \\
\hline Giordano et al. (2004) [31] & USA & 2537 & 1973-1998 & 63 & 41 & \\
\hline $\begin{array}{c}\text { Chakravarthy \& Kim(2002) } \\
\text { [109] }\end{array}$ & USA & 44 & 1967-1995 & 75 & & \\
\hline Schaub et al. (2008) [89] & USA & 28 & $1975-2005$ & $43(51)$ & & \\
\hline Yu et al. (2012) [117] & Canada & 75 & $1977-2006$ & 74 & 37 & 66 \\
\hline Goss et al. (1999) [83] & Canada & 229 & 1955-1996 & 53 & & 47 \\
\hline De Ieso et al. (2012) [175] & Australien & 63 & $1977-2007$ & 85 & & \\
\hline Schuchardt et al. (1996) [116] & Tyskland & 21 & 1972-1993 & 59 & 46 & \\
\hline Sandler et al. (1994) [16] & Tyskland & 28 & & 43 & & \\
\hline Foerster et al. (2011) [170] & Tyskland & 108 & 1995-2007 & 71 & & 53 \\
\hline Zabel et al. (2005) [119] & Tyskland & 31 & & 57 & 44 & \\
\hline Müller et al. (2012) [159] & Tyskland & 40 & $1982-2007$ & 66 & 43 & 79 \\
\hline Herman et al. (2000) [177] & Poland & 65 & & 70 & 60 & \\
\hline De Perrot et al. (2000) [178] & Schweiz & 37 & 1968-1998 & & 44 & \\
\hline Stierer et al.(1995) [38] & Österike & 169 & 1970-1991 & 62 & & 55 \\
\hline Cutuli et al. (1995) [87] & Frankrike & 397 & 1970-1992 & 65 & 38 & 74 \\
\hline Cutuli et al. (2010) [112] & Frankrike & 489 & 1990-2005 & 81 & 59 & \\
\hline Marchal et al. (2009) [179] & Frankrike & 58 & 1980-2002 & 59 & 34 & \\
\hline Dabakuyo et al. (2012) [180] & Frankrike & 75 & 1982-2008 & 69 & & \\
\hline Salvadori et al. (1994) [167] & Italien & 170 & & 73 & 56 & \\
\hline Izquierdo et al. (1994) [128] & Spanien & 50 & 1964-1990 & 75 & & 59 \\
\hline Thalib \& Hall (2009) [181] & Sverige & 269 & 1970-1997 & 79 & & 75 \\
\hline Liukkonen et al. (2010) [27] & Finland & 58 & 1981-2006 & 75 & & \\
\hline Arslan et al. (2012) [173] & Turkiet & 118 & 1986-2009 & 82 & & 60 \\
\hline Atahan et al. (2006) [121] & Turkiet & 42 & & 77 & & 45 \\
\hline Atalay et al. (2003) [81] & Turkiet & 55 & 1990-1998 & 73 & & 45 \\
\hline Eryilmaz et al. (2012) [24] & Turkiet & 25 & & 53 & & 49 \\
\hline $\begin{array}{l}\text { Selcukbiricik et al. (2013) } \\
\text { [93] }\end{array}$ & Turkiet & 86 & $1973-2010$ & 66 & & 72 \\
\hline Ulutin et al. (1998) [182] & Turkiet & 15 & 1980-1995 & 60 & & \\
\hline Engin \& Unsal (1993) [183] & Turkiet & 26 & 1980-1988 & 27 & & \\
\hline Anan et al. (2004) [160] & Japan & 14 & & 92 & 77 & \\
\hline
\end{tabular}




\begin{tabular}{|c|c|c|c|c|c|c|}
\hline Tajima et al. (2001) [184] & Japan & 182 & 1966-1995 & 58 & & \\
\hline Chung et al. (1991) [185] & Sydkorea & 16 & $1970-1990$ & 57 & 28 & \\
\hline Parker et al. (2008) [186] & Sydkorea & 20 & $1985-2007$ & 86 & 76 & 92 \\
\hline Xia et al. (2010) [158] & Kina & 35 & $1969-2004$ & 82 & & 60 \\
\hline Zhou et al. (2010a) [82] & Kina & 72 & 1969-2009 & 72 & & \\
\hline Liu et al. (2011) [187] & Kina & 87 & 1961-2008 & 77 & & 66 \\
\hline Chen et al. (2013) [188] & Kina & 150 & 1980-2012 & 74 & 54 & 66 \\
\hline Baojiang et al. (2012) [189] & Kina & 42 & 1982-2006 & 75 & 52 & 61 \\
\hline Rai et al. (2005) [190] & Indien & 30 & $1996-2000$ & 40 & & \\
\hline Shah et al. (2012) [23] & Indien & 28 & 2001-2008 & & & 46 \\
\hline Salehi et al. (2011) [25] & Iran & 64 & 1989-2008 & 66 & & \\
\hline Temmim et al. (2001) [165] & Kuwait & 41 & 1979-1996 & 67 & & 58 \\
\hline $\begin{array}{l}\text { El-Beshbeshi \& Abo-Elnaga } \\
\text { (2012) [191] }\end{array}$ & Egypten & 37 & 2000-2009 & 61 & & 53 \\
\hline Ahmed et al. (2012) [192] & Nigeria & 57 & $2001-2010$ & 23 & & \\
\hline Ihekwaba (1994) [193] & Nigeria & 57 & $1971-1990$ & 7 & & \\
\hline
\end{tabular}

Table 3. The 5-year survival rate (\%) with respect to tumour size in different studies.

\begin{tabular}{ccccc}
\hline Study (year) & T1 & T2 & T3 & T4 \\
\hline Selcukbiricik et al. (2013) [93] & 92 & 74 & 41 & 57 \\
Zhou et al. (2010) [82] & 100 & 74 & 40 & 0 \\
Giordano et al. (2004) [31] & 78 & 67 & 27 & 5 \\
Vaizey et al. (1999) [194] & 88 & 50 & 43 & - \\
Ribeiro et al. (1996) [86] & 76 & 66 & \\
\hline
\end{tabular}

lymph node status [5] [25] [31] [38] [43] [83] [87] [115] [119] [125] [163] [172] [173] [175] [176], which means that positive lymph node status results in a lower 5-year survival rate (Table 4) and with the number of positive nodes in the lymph nodes in the armpit [38] [87] [115] [163].

\section{Conclusion}

Breast cancer in men is a rare disease compared to women and it is frequently diagnosed with more advanced stage of disease. Because of high median age for occurrence and also high hormone positivity rate, hormone therapy such as tamoxifen is generally considered a standard adjuvant therapy [1] and theoretically very promising [12]. However, the relationship between hormone positivity and survival benefit with hormonal therapy is less clear in men than in women. The role of adjuvant aromatase inhibitors in MBC has not been determined, and preclinical data suggest that aromatase inhibitors may be less effective in men [19]. Therefore, tamoxifen remains as first line hormone therapy till further large-scale data are available [13]. The role for adjuvant chemotherapy in men is also not adequately established [19], but the limited data do suggest a benefit [12]. It is not simple to evaluate the relative benefit of hormonal therapy and chemotherapy, but it seems that the patients being treated with systemic therapies have had longer time to disease recurrence and survival [1]. Limited data are available for determining which patients need radiation therapy after operation [12], and the use of radiation therapy is extremely heterogeneous in the literature [1], but this therapy should be delivered more often in men with breast cancer than in women, due to the high proportion of locally advanced disease, axillary nodal 
Table 4. The 5-year survival rate (\%) with repect to lymph node status in different studies.

\begin{tabular}{ccc}
\hline Study (year) & Node negative & Node positive \\
\hline Goss et al. (1999) [83] & 68 & 47 \\
Stranzl et al. (1999) [120] & 91 & 71 \\
Guinee et al. (1993) [163] & 78 & 35 \\
Borgen et al. (1992) [14] & 87 & 54 \\
Giordano et al. (2004) [31] & 76 & $<54$ \\
Teo et al. (2012) [22] & 70 & 68.5 \\
Kiluk et al. (2011) [195] & 87.5 & 45 \\
Salehi et al. (2011) [25] & 68 & \\
\hline
\end{tabular}

involvement and central tumour location [1]. We need a greater awareness of male breast cancer to guide evidence-based treatment and to encourage enrollment in future studies aiming at optimizing management of this rare disease. The role of adjuvant hormonal treatment and chemotherapy deserves more researches, especially to determine which subgroup of men will benefit.

\section{References}

[1] Cutuli, B. (2007) Strategies in Treating Male Breast Cancer. Expert Opinion on Pharmacotherapy, 8, 193-202. http://dx.doi.org/10.1517/14656566.8.2.193

[2] Gennari, R., et al. (2004) Male Breast Cancer: A Special Therapeutic Problem. Anything New? (Review). International Journal of Oncology, 24, 663-670.

[3] Fentiman, I.S., et al. (2006) Male Breast Cancer. The Lancet, 367, 595-604. http://dx.doi.org/10.1016/S0140-6736(06)68226-3

[4] Jamal, S., Mamoon, N., Mushtaq, S., et al. (2006) Carcinoma of the Male Breast: A Study of 141 Cases from Northern Pakistan. Asian Pacific Journal of Cancer Prevention, 7, 119-121.

[5] Yoney, A., Kucuk, A. and Unsal, M. (2009) Male Breast Cancer: A Retrospective Analysis. Cancer/Radiothérapie, 13, 103-107. http://dx.doi.org/10.1016/j.canrad.2008.11.011

[6] Donegan, W.L. and Redlich, P.N. (1996) Breast Cancer in Men. Surgical Clinics of North America, 76, 343-363. http://dx.doi.org/10.1016/S0039-6109(05)70443-6

[7] Crichlow, R.W. and Galt, S.W. (1990) Male Breast Cancer. Surgical Clinics of North America, 70, 1165-1177.

[8] Burga, A.M., Fadare, O., Lininger, R.A., et al. (2006) Invasive Carcinomas of the Male Breast: A Morphologic Study of the Distribution of Histologic Subtypes and Metastatic Patterns in 778 Cases. Virchows Archiv, 449, 507-512. http://dx.doi.org/10.1007/s00428-006-0305-3

[9] Weiss, J.R., et al. (2005) Epidemiology of Male Breast Cancer. Cancer Epidemiology, Biomarkers Prevention, 14, 20-26.

[10] Donegan, W.L., et al. (1998) Carcinoma of the Breast in Males: A Multiinstitutional Survey. Cancer, 83, 498-509. http://dx.doi.org/10.1002/(SICI)1097-0142(19980801)83:3<498::AID-CNCR19>3.0.CO;2-R

[11] Ravandi-Kashani, F. and Hayes, T.G. (1998) Male Breast Cancer: A Review of the Literature. European Journal of Cancer, 34, 1341-1347.

[12] Giordano, S.H., Buzdar, A.U. and Hortobagyi, G.N. (2002) Breast Cancer in Men. Annals of Internal Medicine, 137, 678-687. http://dx.doi.org/10.7326/0003-4819-137-8-200210150-00013

[13] Agrawal, A., Ayantunde, A.A., Rampaul, R. and Robertson, J.F. (2007) Male Breast Cancer: A Review of Clinical Management. Breast Cancer Research and Treatment, 103, 11-21.

[14] Borgen, P.I., Wong, G.Y., Vlamis, V., Potter, C., Hoffmann, B., Kinne, D.W., Osborne, M.P. and Mckinnon, W. (1992) Current Management of Male Breast Cancer. A Review of 104 Cases. Annals of Surgery, 215, 451. http://dx.doi.org/10.1097/00000658-199205000-00007

[15] Willsher, P.C., Leach, I.H., Ellis, I.O., Bell, J.A., Elston, C.W., Bourke, J.B., Blamey, R.W. and Robertson, J.F.R. (1997) Male Breast Cancer: Pathological and Immunohistochemical Features. Anticancer Research, 17, 2335-2338.

[16] Sandler, B., Carman, C. and Perry, R.R. (1994) Cancer of the Male Breast. American Surgeon, 60, 816-820.

[17] Shukla, N.K., Seenu, V., Goel, A.K., Raina, V., Rath, G.K., Singh, R., Kriplani, A.K., Deo, S.V. and Misra, M.C. 
(1996) Male Breast Cancer: A Retrospective Study from a Regional Cancer Center in Northern India. Journal of Surgical Oncology, 61, 143-148. http://dx.doi.org/10.1002/(SICI)1096-9098(199602)61:2<143::AID-JSO10>3.0.CO;2-A

[18] Hassan, I. and Mabogunje, O. (1995) Cancer of the Male Breast in Zaria, Nigeria. East African Medical Journal, 72, 457-458.

[19] Rudlowski, C. (2008) Male Breast Cancer. Breast Care, 3, 183-189.

[20] Borgen, P.I. (1991) Male Breast Cancer. Seminars in Surgical Oncology, 7, 314-319. http://dx.doi.org/10.1002/ssu.2980070516

[21] Ciatto, S., Iossa, A., Bonardi, R. and Pacini, P. (1990) Male Breast Carcinoma: Review of a Multicenter Series of 150 Cases. Coordinating Center and Writing Committee of FONCAM (National Task Force for Breast Cancer), Italy. Tumori, 76, 555-558.

[22] Teo, J.Y., Tan, P.H. and Yong, W.S. (2012) Male Breast Cancer in Singapore: 15 Years of Experience at a Single Tertiary Institution. Annals of the Academy of Medicine, Singapore, 41, 247-251.

[23] Shah, S., Bhattacharyya, S., Gupta, A., Ghosh, A. and Basak, S. (2012) Male Breast Cancer: A Clinicopathologic Study of 42 Patients in Eastern India. Indian Journal of Surgical Oncology, 3, 245-249. http://dx.doi.org/10.1007/s13193-012-0163-1

[24] Eryilmaz, M.A., Igci, A., Muslumanoglu, M., Ozmen, V. and Koc, M. (2012) Male Breast Cancer: A Retrospective Study of 15 Years. Journal of Balkan Union of Oncology, 17, 51-56.

[25] Salehi, A., Zeraati, H., Mohammad, K., Mahmoudi, M., Talei, A.R., Ghaderi, A., Imanieh, M.H. and Fotouhi, A. (2011) Survival of Male Breast Cancer in Fars, South of Iran. Iranian Red Crescent Medical Journal, 13, 99-105.

[26] Bourhafour, M., Belbaraka, R., Souadka, A., M’rabti, H., Tijami, F. and Errihani, H. (2011) Male Breast Cancer: A Report of 127 Cases at a Moroccan Institution. BMC Research Notes, 4, 219. http://dx.doi.org/10.1186/1756-0500-4-219

[27] Liukkonen, S., Saarto, T., Maenpaa, H. and Sjöström-Mattson, J. (2010) Male Breast Cancer: A Survey at the Helsinki University Central Hospital during 1981-2006. Acta Oncologica, 49, 322-327. http://dx.doi.org/10.3109/02841861003591723

[28] Di Benedetto, G., Pierangeli, M. and Bertani, A. (1998) Carcinoma of the Male Breast: An Underestimated Killer. Plastic \& Reconstructive Surgery, 102, 696-700. http://dx.doi.org/10.1097/00006534-199809010-00012

[29] Ngoo, K.S., Rohaizak, M., Naqiyah, I. and Shahrun Niza, A.S. (2009) Male Breast Cancer: Experience from a Malaysian Tertiary Centre. Singapore Medical Journal, 50, 519-521.

[30] Kidmas, A.T., Ugwu, B.T., Manasseh, A.N., Iya, D. and Opaluwa, A.S. (2005) Male Breast Malignancy in Jos University Teaching Hospital. West African Journal of Medicine, 24, 36-40.

[31] Giordano, S.H., Cohen, D.S., Buzdar, A.U., Perkins, G. and Hortobagyi, G.N. (2004) Breast Carcinoma in Men: A Population-Based Study. Cancer, 101, 51-57. http://dx.doi.org/10.1002/cncr.20312

[32] El Omari-Alaoui, H., Lahdiri, I., Nejjar, I., Hadadi, K., Ahyoud, F., Hachi, H., et al. (2002) Male Breast Cancer. A Report of 71 Cases. Cancer/Radiothérapie, 6, 349-351. http://dx.doi.org/10.1016/S1278-3218(02)00250-0

[33] Chantra, P.K., So, G.J., Wollman, J.S. and Bassett, L.W. (1995) Mammography of the Male Breast. American Journal of Roentgenology, 164, 853-858.

[34] O’Hanlon, D.M., Kent, P., Kerin, M.J. and Given, H.F. (1995) Unilateral Breast Masses in Men over 40: A Diagnostic Dilemma. American Journal of Surgery, 170, 24-26. http://dx.doi.org/10.1016/S0002-9610(99)80246-3

[35] Jamal, S., et al. (1994) Malignant Tumors of the Male Breast-A Review of 50 Cases. Journal of Pakistan Medical Association, 44, 275-277.

[36] Gough, D.B., Donohue, J.H., Evans, M.M., Pernicone, P.J., Wold, L.E., Naessens, J.M. and O’Brien, P.C. (1993) A 50-Year Experience of Male Breast Cancer: Is Outcome Changing? Surgical Oncology, 2, 325-333. http://dx.doi.org/10.1016/0960-7404(93)90063-5

[37] Dershaw, D.D., Borgen, P.I., Deutch, B.M. and Liberman, L. (1993) Mammographic Findings in Men with Breast Cancer. American Journal of Roentgenology, 160, 267-270. http://dx.doi.org/10.2214/ajr.160.2.8424331

[38] Stierer, M., Rosen, H., Weitensfelder, W., Hausmaninger, H., Teleky, B., Jakesz, R., et al. (1995) Male Breast Cancer: Austrian Experience. World Journal of Surgery, 19, 687-692. http://dx.doi.org/10.1007/BF00295904

[39] Mathew, J., Perkins, G.H., Stephens, T., Middleton, L.P. and Yang, W.T. (2008) Primary Breast Cancer in Men: Clinical, Imaging, and Pathologic Findings in 57 Patients. American Journal of Roentgenology, 191, 1631-1639.

[40] Joshi, M.G., Lee, A.K.C., Loda, M., Camus, M.G., Pedersen, C., Heatley, G.J. and Hughes, K.S. (1996) Male Breast Carcinoma: An Evaluation of Prognostic Factors Contributing to a Poorer Outcome. Cancer, 77, 490-498. http://dx.doi.org/10.1002/(SICI)1097-0142(19960201)77:3<490::AID-CNCR10>3.0.CO;2-\# 
[41] Onami, S., Ozaki, M., Mortimer, J.E. and Pal, S.K. (2010) Male Breast Cancer: An Update in Diagnosis, Treatment and Molecular Profiling. Maturitas, 65, 308-314. http://dx.doi.org/10.1016/j.maturitas.2010.01.012

[42] Muñoz Carrasco, R., Álvarez Benito, M. and del Campo, E.R. (2013) Value of Mammography and Breast Ultrasound in Male Patients with Nipple Discharge. European Journal of Radiology, 82, 478-484. http://dx.doi.org/10.1016/j.ejrad.2012.10.019

[43] Tural, D., Selçukbiricik, F., Aydoğan, F., Beşe, N., Yetmen, Ö., İlvan, Ş., Büyükünal, E. and Serdengeçti, S. (2013) Male Breast Cancers Behave Differently in Elderly Patients. Japanese Journal of Clinical Oncology, 43, 22-27. http://dx.doi.org/10.1093/jjco/hys193

[44] Iuanow, E., Kettler, M. and Slanetz, P.J. (2011) Spectrum of Disease in the Male Breast. American Journal of Roentgenology, 196, W247-W259.

[45] Adibelli, Z.H., Oztekin, O., Postaci, H. and Uslu, A. (2009) The Diagnostic Accuracy of Mammography and Ultrasound in the Evaluation of Male Breast Disease: A New Algorithm. Breast Care, 4, 255-259. http://dx.doi.org/10.1159/000226284

[46] Lattin Jr., G.E., Jesinger, R.A., Mattu, R. and Glassman, L.M. (2013) From the Radiologic Pathology Archives: Diseases of the Male Breast: Radiologic-Pathologic Correlation. RadioGraphics, 33, 461-489. http://dx.doi.org/10.1148/rg.332125208

[47] Hines, S.L., Tan, W.W., Yasrebi, M., Deperi, E.R. and Perez, E.A. (2007) The Role of Mammography in Male Patients with Breast Symptoms. Mayo Clinic Proceedings, 82, 297-300. http://dx.doi.org/10.1016/S0025-6196(11)61025-2

[48] Günhan-Bilgen, I., Bozkaya, H., Üstün, E.E. and Memiş, A. (2002) Male Breast Disease: Clinical, Mammographic, and Ultrasonographic Features. European Journal of Radiology, 43, 246-255. http://dx.doi.org/10.1016/S0720-048X(01)00483-1

[49] Cooper, R.A., Gunter, B.A. and Ramamurthy, L. (1994) Mammography in Men. Radiology, 191, 651-656. http://dx.doi.org/10.1148/radiology.191.3.8037795

[50] Evans, G.F.F., Anthony, T., Appelbaum, A.H., Schumpert, T.D., Levy, K.R., Amirkhan, R.H., Cambell, T.J., Lopez, J. and Turnage, R.H. (2001) The Diagnostic Accuracy of Mammography in the Evaluation of Male Breast Disease. American Journal of Surgery, 181, 96-100. http://dx.doi.org/10.1016/S0002-9610(00)00571-7

[51] Williams, W.L. Jr., Powers, M. and Wagman, L.D. (1996) Cancer of the Male Breast: A Review. Journal of the National Medical Association, 88, 439-442.

[52] Volpe, C.M., Raffetto, J.D., Collure, D.W., Hoover, E.L. and Doerr, R.J. (1999) Unilateral Male Breast Masses: Cancer Risk and Their Evaluation and Management. American Surgeon, 65, 250-253.

[53] Yitta, S., Singer, C.I., Toth, H.B. and Mercado, C.L. (2010) Image Presentation. Sonographic Appearances of Benign and Malignant Male Breast Disease with Mammographic and Pathologic Correlation. Journal of Ultrasound in Medicine, 29, 931-947.

[54] Bazzocchi, M., Vianello, E., Linda, A., Londero, V. and Zuiani, C. (2010) Male Breast Lesions: Which Abnormalities Really Need Core Needle Biopsy? Tumori, 96, 266-270.

[55] Chen, L., Chantra, P.K., Larsen, L.H., Barton, P., Rohitopakarn, M., Zhu, E.Q. and Bassett, L.W. (2006) Imaging Characteristics of Malignant Lesions of the Male Breast. RadioGraphics, 26, 993-1006. http://dx.doi.org/10.1148/rg.264055116

[56] Hines, S.L., Tan, W., Larson, J.M., Thompson, K.M., Jorn, H.K. and Files, J.A. (2008) A Practical Approach to Guide Clinicians in the Evaluation of Male Patients with Breast Masses. Geriatrics, 63, 19-24.

[57] Korde, L.A., Zujewski, J.A., Kamin, L., Giordano, S., Domchek, S., Anderson, W.F., et al. (2010) Multidisciplinary Meeting on Male Breast Cancer: Summary and Research Recommendations. Journal of Clinical Oncology, 28, 21142122. http://dx.doi.org/10.1200/JCO.2009.25.5729

[58] Hanavadi, S., Monypenny, I.J. and Mansel, R.E. (2006) Is Mammography Overused in Male Patients? The Breast, 15, 123-126. http://dx.doi.org/10.1016/j.breast.2005.02.005

[59] Applebaum, A.H., Evans, G.F., Levy, K.R., Amirkhan, R.H. and Schumpert, T.D. (1999) Mammographic Appearances of Male Breast Disease. RadioGraphics, 19, 559-568. http://dx.doi.org/10.1148/radiographics.19.3.g99ma01559

[60] Draghi, F., Tarantino, C.C., Madonia, L. and Ferrozzi, G. (2011) Ultrasonography of the Male Breast. Journal of Ultrasound, 14, 122-129. http://dx.doi.org/10.1016/j.jus.2011.06.004

[61] Reis, L.O., Gf Dias, F., As Castro, M. and Ferreira, U. (2011) Male Breast Cancer. Aging Male, 14, 99-109. http://dx.doi.org/10.3109/13685538.2010.535048

[62] Yang, W.T., Whitman, G.J., Yuen, E.H.Y., Tse, G.M.K. and Stelling, C.B. (2001) Sonographic Features of Primary Breast Cancer in Men. American Journal of Roentgenology, 176, 413-416.

[63] Stewart, R.A., Howlett, D.C. and Hearn, F.J. (1997) Pictorial Review: The Imaging Features of Male Breast Disease. 
Clinical Radiology, 52, 739-744. http://dx.doi.org/10.1016/S0009-9260(97)80151-1

[64] Charlot, M., Béatrix, O., Chateau, F., Dubuisson, J., Golfier, F., Valette, P.J. and Réty, F. (2013) Pathologies of the Male Breast. Diagnostic and Interventional Imaging, 94, 26-37. http://dx.doi.org/10.1016/j.diii.2012.10.011

[65] Adibelli, Z.H., Oztekin, O., Gunhan-Bilgen, I., Postaci, H., Uslu, A. and Ilhan, E. (2010) Imaging Characteristics of Male Breast Disease. Breast Journal, 16, 510-518. http://dx.doi.org/10.1111/j.1524-4741.2010.00951.x

[66] Patterson, S.K., Helvie, M.A., Aziz, K. and Nees, A.V. (2006) Outcome of Men Presenting with Clinical Breast Problems: The Role of Mammography and Ultrasound. Breast Journal, 12, 418-423. http://dx.doi.org/10.1111/j.1075-122X.2006.00298.x

[67] Taylor, K., Ames, V. and Wallis, M. (2013) The Diagnostic Value of Clinical Examination and Imaging Used as Part of an Age-Related Protocol When Diagnosing Male Breast Disease: An Audit of 1141 Cases from a Single Centre. Breast, 22, 268-272. http://dx.doi.org/10.1016/j.breast.2013.03.004

[68] Morrogh, M. and King, T.A. (2009) The Significance of Nipple Discharge of the Male Breast. Breast Journal, 15, 632638. http://dx.doi.org/10.1111/j.1524-4741.2009.00818.x

[69] Vetto, J., Schmidt, W., Pommier, R., Ditomasso, J., Eppich, H., Wood, W. and Moseson, D. (1998) Accurate and Cost-Effective Evaluation of Breast Masses in Males. American Journal of Surgery, 175, 383-387. http://dx.doi.org/10.1016/S0002-9610(98)00046-4

[70] Fentiman, I.S. (2009) Male Breast Cancer: A Review. Ecancermedicalscience, 3, 140.

[71] Rosen, D.G., Laucirica, R. and Verstovsek, G. (2009) Fine Needle Aspiration of Male Breast Lesions. Acta Cytologica, 53, 369-374. http://dx.doi.org/10.1159/000325335

[72] Westenend, P.J. and Jobse, C. (2002) Evaluation of Fine-Needle Aspiration Cytology of Breast Masses in Males. Cancer, 96, 101-104.

[73] Lilleng, R., Paksoy, N., Vural, G., Langmark, F. and Hagmar, B. (1995) Assessment of Fine Needle Aspiration Cytology and Histopathology for Diagnosing Male Breast Masses. Acta Cytologica, 39, 877-881.

[74] Das, D.K., Junaid, T.A., Mathews, S.B., Ajrawi, T.G., Ahmed, M.S., Madda, J.P. and Mirza, K. (1995) Fine Needle Aspiration Cytology Diagnosis of Male Breast Lesions. A Study of 185 Cases. Acta Cytologica, 39, 870-876.

[75] Sneige, N., Holder, P.D., Katz, R.L., Fanning, C.V., Dekmezian, R.H., Shabb, N.S. and Singletary, S.E. (1993) Fine-Needle Aspiration Cytology of the Male Breast in a Cancer Center. Diagnostic Cytopathology, 9, 691-697. http://dx.doi.org/10.1002/dc.2840090619

[76] Gupta, R.K., Naran, S., Dowle, C.S. and Simpson, J.S. (1991) The Diagnostic Impact of Needle Aspiration Cytology of the Breast on Clinical Decision Making with an Emphasis on the Aspiration Cytodiagnosis of the Male Breast. Diagnostic Cytopathology, 7, 637-639. http://dx.doi.org/10.1002/dc.2840070620

[77] Westenend, P.J. (2003) Core Needle Biopsy in Male Breast Lesions. Journal of Clinical Pathology, 56, 863-865. http://dx.doi.org/10.1136/jcp.56.11.863

[78] Zhou, F.F., Xia, L.P., Guo, G.F., Wang, X., Yuan, Z.Y., Zhang, B. and Wang, F. (2010) Changes in Therapeutic Strategies in Chinese Male Patients with Breast Cancer: 40 Years of Experience in a Single Institute. Breast, 19, 450-455. http://dx.doi.org/10.1016/j.breast.2010.04.007

[79] Contractor, K.B., Kaur, K., Rodrigues, G.S., Kulkarni, D.M. and Singhal, H. (2008) Male Breast Cancer: Is the Scenario Changing. World Journal of Surgical Oncology, 6, 58. http://dx.doi.org/10.1186/1477-7819-6-58

[80] La Pinta, M., Fabi, A., Ascarelli, A., Ponzani, T., Di Carlo, V., Scicchitano, F., Saputo, S., Russillo, M. and Andrich, R. (2008) Male Breast Cancer: 6-Year Experience. Minerva Chirurgica, 63, 71-78.

[81] Atalay, C., Kanlioz, M. and Altinok, M. (2003) Prognostic Factors Affecting Survival in Male Breast Cancer. Journal of Experimental \& Clinical Cancer Research, 22, 29-33.

[82] Zhou, F.F., Xia, L.P., Wang, X., Guo, G.F., Rong, Y.M., Qiu, H.J. and Zhang, B. (2010) Analysis of Prognostic Factors in Male Breast Cancer: A Report of 72 Cases from a Single Institution. Chinese Journal of Cancer, 29, 184-188. http://dx.doi.org/10.5732/cjc.009.10499

[83] Goss, P.E., Reid, C., Pintilie, M., Lim, R. and Miller, N. (1999) Male Breast Carcinoma: A Review of 229 Patients Who Presented to the Princess Margaret Hospital during 40 Years: 1955-1996. Cancer, 85, 629-639. http://dx.doi.org/10.1002/(SICI)1097-0142(19990201)85:3<629::AID-CNCR13>3.0.CO;2-V

[84] El-Tamer, M.B., Komenaka, I.K., Troxel, A., Li, H.L., Joseph, K.A., Ditkoff, B.A., Schnabel, F.R. and Kinne, D.W. (2004) Men with Breast Cancer Have Better Disease-Specific Survival than Women. JAMA Surgery, 139, 1079-1082. http://dx.doi.org/10.1001/archsurg.139.10.1079

[85] Margaria, E., Chiusa, L., Ferrari, L., Dal Canton, O. and Pich, A. (2000) Therapy and Survival in Male Breast Carcinoma: A Retrospective Analysis of 50 Cases. Oncology Reports, 7, 1035-1039.

[86] Ribeiro, G., Swindell, R., Harris, M., Banerjee, S.S. and Cramer, A. (1996) A Review of the Management of the Male 
Breast Carcinoma Based on an Analysis of 420 Treated Cases. Breast, 5, 141-146.

[87] Cutuli, B., Lacroze, M., Dilhuydy, J.M., Veiten, M., De Lafontan, B., Marchal, C., Resbeut, M., et al. (1995) Male Breast Cancer: Results of the Treatments and Prognostic Factors in 397 Cases. European Journal of Cancer, 31, 1960 1964. http://dx.doi.org/10.1016/0959-8049(95)00366-5

[88] Zygogianni, A.G., Kyrgias, G., Gennatas, C., Ilknur, A., Armonis, V., Tolia, M., et al. (2012) Male Breast Carcinoma: Epidemiology, Risk Factors and Current Therapeutic Approaches. Asian Pacific Journal of Cancer Prevention, 13, 15-19. http://dx.doi.org/10.7314/APJCP.2012.13.1.015

[89] Schaub, N.P., Maloney, N., Schneider, H., Feliberti, E. and Perry, R. (2008) Changes in Male Breast Cancer over a 30-Year Period. The American Surgeon, 74, 707-712.

[90] Scott-Conner, C.E., Jochimsen, P.R., Menck, H.R. and Winchester, D.J. (1999) An Analysis of Male and Female Breast Cancer Treatment and Survival among Demographically Identical Pairs of Patients. Surgery, 126, 775-780, Discussion 780-771.

[91] Vinod, S.K. and Pendlebury, S.C. (1999) Carcinoma of the Male Breast: A Review of Adjuvant Therapy. Australasian Radiology, 43, 69-72. http://dx.doi.org/10.1046/j.1440-1673.1999.00601.x

[92] Gómez-Raposo, C., Tévar, F.Z., Moyano, M.S., Gómez, M.L. and Casado, E. (2010) Male Breast Cancer. Cancer Treatment Reviews, 36, 451-457. http://dx.doi.org/10.1016/j.ctrv.2010.02.002

[93] Selcukbiricik, F., Tural, D., Aydoğan, F., Beşe, N., Büyükünal, E. and Serdengeçti, S. (2013) Male Breast Cancer: 37-Year Data Study at a Single Experience Center in Turkey. Journal of Breast Cancer, 16, 60-65. http://dx.doi.org/10.4048/jbc.2013.16.1.60

[94] Giordano, S.H., Perkins, G.H., Broglio, K., Garcia, S.G., Middleto, L.P., Buzdar, A.U. and Hortobagyi, G.N. (2005) Adjuvant Systemic Therapy for Male Breast Carcinoma. Cancer, 104, 2359-2364. http://dx.doi.org/10.1002/cncr.21526

[95] Ruddy, K.J. and Winer, E.P. (2013) Male Breast Cancer: Risk Factors, Biology, Diagnosis, Treatment, and Survivorship. Annals of Oncology, 24, 1434-1443.

[96] Cloyd, J.M., Hernandez-Boussard, T. and Wapnir, I.L. (2013) Outcomes of Partial Mastectomy in Male Breast Cancer Patients: Analysis of SEER, 1983-2009. Annals of Surgical Oncology, 20, 1545-1550. http://dx.doi.org/10.1245/s10434-013-2918-5

[97] Pant, K. and Dutta, U. (2008) Understanding and Management of Male Breast Cancer: A Critical Review. Medical Oncology, 25, 294-298. http://dx.doi.org/10.1007/s12032-007-9034-y

[98] Yıldırım, E. and Berberoğlu, U. (1998) Male Breast Cancer: A 22-Year Experience. European Journal of Surgical Oncology, 24, 548-552. http://dx.doi.org/10.1016/S0748-7983(98)93608-3

[99] Flynn, L.W., Park, J., Patil, S.M., Cody, H.S. and Port, E.R. (2008) Sentinel Lymph Node Biopsy Is Successful and Accurate in Male Breast Carcinoma. Journal of the American College of Surgeons, 206, 616-621. http://dx.doi.org/10.1016/j.jamcollsurg.2007.11.005

[100] Gentilini, O., Chagas, E., Zurrida, S., Intra, M., De Cicco, C. and Gatti, G. (2007) Sentinel Lymph Node Biopsy in Male Patients with Early Breast Cancer. Oncologist, 12, 512-515. http://dx.doi.org/10.1634/theoncologist.12-5-512

[101] Rusby, J.E., Smith, B.L., Dominguez, F.J. and Golshan, M. (2006) Sentinel Lymph Node Biopsy in Men with Breast Cancer: A Report of 31 Consecutive Procedures and Review of Literature. Clinical Breast Cancer, 7, 406-410. http://dx.doi.org/10.3816/CBC.2006.n.058

[102] Boughey, J.C., Bedrosian, I., Meric-Bernstam, F., Ross, M.I., Kuerer, H.M., Akins, J.S., et al. (2006) Comparative Analysis of Sentinel Lymph Node Operation in Male and Female Breast Cancer Patients. Journal of the American College of Surgeons, 203, 475-480. http://dx.doi.org/10.1016/j.jamcollsurg.2006.06.014

[103] De Cicco, C., Baio, S.M., Veronesi, P., et al. (2004) Sentinel Node Biopsy in Male Breast Cancer. Nuclear Medicine Communications, 25, 139-143.

[104] Goyal, A., Horgan, K., Kissin, M., Yiangou, C., Sibbering, M., Lansdown, M., Newcombe, R.G. and Mansel, R.E. (2004) Sentinel Lymph Node Biopsy in Male Breast Cancer Patients. European Journal of Surgical Oncology, 30, 480-483. http://dx.doi.org/10.1016/j.ejso.2004.02.006

[105] Cimmino, V.M., Degnim, A.C., Sabel, M.S., Diehl, K.M., Newman, L.A. and Chang, A.E. (2004) Efficacy of Sentinel Lymph Node Biopsy in Male Breast Cancer. Journal of Surgical Oncology, 86, 74-77. http://dx.doi.org/10.1002/jso.20045

[106] Albo, D., Ames, F.C., Hunt, K.K., Ross, M.I., Singletary, S.E. and Kuerer, H.M. (2003) Evaluation of Lymph Node Status in Male Breast Cancer Patients: A Role for Sentinel Lymph Node Biopsy. Breast Cancer Research and Treatment, 77, 9-14. http://dx.doi.org/10.1023/A:1021173902253

[107] Port, E.R., Fey, J.V., Cody III, H.S. and Borgen, P.I. (2001) Sentinel Lymph Node Biopsy in Patients with Male Breast 
Carcinoma. Cancer, 91, 319-323.

http://dx.doi.org/10.1002/1097-0142(20010115)91:2<319::AID-CNCR1004>3.0.CO;2-D

[108] Bratman, S.V., Kapp, D.S. and Horst, K.C. (2012) Evolving Trends in the Initial Locoregional Management of Male Breast Cancer. Breast, 21, 296-302.

[109] Chakravarthy, A. and Kim, C.R. (2002) Post-Mastectomy Radiation in Male Breast Cancer. Radiotherapy and Oncology, 65, 99-103.

[110] De Los Santos, J.F. and Buchholz, T.A. (2000) Carcinoma of the Male Breast. Current Treatment Options in Oncology, 1, 221-227. http://dx.doi.org/10.1007/s11864-000-0033-X

[111] Kamila, C., Jenny, B., Per, H. and Jonas, B. (2007) How to Treat Male Breast Cancer. Breast, 16, 147-154. http://dx.doi.org/10.1016/j.breast.2007.07.024

[112] Cutuli, B., Cohen-Solal Le-Nir, C., Serin, D., Kirova, Y., Gaci, Z., Lemanski, C., De Lafontan, B., et al. (2010) Male Breast Cancer. Evolution of Treatment and Prognostic Factors. Analysis of 489 Cases. Critical Reviews in Oncology/Hematology, 73, 246-254. http://dx.doi.org/10.1016/j.critrevonc.2009.04.002

[113] Kinne, D.W. (1991) Management of Male Breast Cancer. Oncology (Williston Park), 5, 45-47.

[114] Chung, H.C., Koh, E.H., Roh, J.K., Min, J.S., Lee, K.S., Suh, C.O., Kim, K.E., Loh, J.J., Lee, K.B. and Kim, B.S. (1990) Male Breast Cancer-A 20-Year Review of 16 Cases at Yonsei University. Yonsei Medical Journal, 31, 242-250.

[115] Vetto, J., Jun, S.Y., Padduch, D., Eppich, H. and Shih, R. (1999) Stages at Presentation, Prognostic Factors, and Outcome of Breast Cancer in Males. American Journal of Surgery, 177, 379-383. http://dx.doi.org/10.1016/S0002-9610(99)00067-7

[116] Schuchardt, U., Seegenschmiedt, M.H., Kirschner, M.J., Renner, H. and Sauer, R. (1996) Adjuvant Radiotherapy for Breast Carcinoma in Men: A 20-Year Clinical Experience. American Journal of Clinical Oncology, 19, 330-336. http://dx.doi.org/10.1097/00000421-199608000-00002

[117] Yu, E., Suzuki, H., Younus, J., Elfiki, T., Stitt, L., Yau, G., et al. (2012) The Impact of Post-Mastectomy Radiation Therapy on Male Breast Cancer Patients-A Case Series. International Journal of Radiation Oncology • Biology • Physics, 82, 696-700. http://dx.doi.org/10.1016/j.ijrobp.2011.01.010

[118] Yoney, A., Kucuk, A., Alan, O. and Unsal, M. (2008) A Retrospective Study of Treatment and Outcome in 39 Cases of Male Breast Cancer. Hematology/Oncology and Stem Cell Therapy, 1, 98-105. http://dx.doi.org/10.1016/S1658-3876(08)50041-0

[119] Zabel, A., Milker-Zabel, S., Zuna, I., Wannenmacher, M. and Debus, J. (2005) External Beam Radiotherapy in the Treatment of Male Breast Carcinoma: Patterns of Failure in a Single Institute Experience. Tumori, 91, 151-155.

[120] Stranzl, H., Mayer, R., Quehenberger, F., Prettenhofer, U., Willfurth, P., Stöger, H. and Hackl, A. (1999) Adjuvant Radiotherapy in Male Breast Cancer. Radiotherapy and Oncology, 53, 29-35.

[121] Atahan, L., Yildiz, F., Selek, U., Sari, S. and Gurkaynak, M. (2006) Postoperative Radiotherapy in the Treatment of Male Breast Carcinoma: A Single Institute Experience. Journal of the National Medical Association, 98, 559-563.

[122] Hill, A., Yagmoury, Y., Tran, K.N., Bolton, J.S., Robson, M. and Borgen, P.I. (1999) Localized Male Breast Carcinoma and Family History. An Analysis of 142 Patients. Cancer, 86, 821-825. http://dx.doi.org/10.1002/(SICI)1097-0142(19990901)86:5<821::AID-CNCR18>3.0.CO;2-I

[123] Chakravarthy, A. and Kim, C.R. (2002) Post-Mastectomy Radiation in Male Breast Cancer. Radiotherapy and Oncology, 65, 99-103. http://dx.doi.org/10.1016/S0167-8140(02)00210-4

[124] Eggemann, H., Ignatov, A., Stabenow, R., Von Minckwitz, G., Röhl, F.W., Hass, P. and Costa, S.D. (2013) Male Breast Cancer: 20-Year Survival Data for Post-Mastectomy Radiotherapy. Breast Care (Basel), 8, 270-275. http://dx.doi.org/10.1159/000354122

[125] Akbulut, S., Arer, I., Kocbiyik, A., Can Yağmurdur, M., Karakayali, H. and Haberal, M. (2009) Male Breast Cancer: Thirteen Years' Experience of a Single Center. International Seminars in Surgical Oncology, 6, 4. http://dx.doi.org/10.1186/1477-7800-6-4

[126] Meguerditchian, A.N., Falardeau, M. and Martin, G. (2002) Male Breast Carcinoma. Canadian Journal of Surgery, 45, 296-302.

[127] Jaiyesimi, I.A., Buzdar, A.U., Sahin, A.A. and Ross, M.A. (1992) Carcinoma of the Male Breast. Annals of Internal Medicine, 117, 771-777. http://dx.doi.org/10.7326/0003-4819-117-9-771

[128] Izquierdo, M.A., Alonso, C., de Andres, L. and Ojeda, B. (1994) Male Breast Cancer Report of a Series of 50 Cases. Acta Oncologica, 33, 767-771. http://dx.doi.org/10.3109/02841869409083946

[129] Ying, M., Agrawal, A. and Cheung, K.L. (2005) The “Other Half” of Breast Cancer: A Review of Male Breast Cancer. Journal of Men's Health and Gender, 2, 406-413. http://dx.doi.org/10.1016/j.jmhg.2005.10.012 
[130] Fogh, S., Hirsch, A.E., Goldberg, S.I., Rosenberg, C.L., Taghian, A.G., Powell, S.N., Kachnic, L.A. and Langmead, J.P. (2011) Use of Tamoxifen with Postsurgical Irradiation May Improve Survival in Estrogen and Progesterone Receptor-Positive Male Breast Cancer. Clinical Breast Cancer, 11, 39-45. http://dx.doi.org/10.3816/CBC.2011.n.007

[131] Ribeiro, G. and Swindell, R. (1992) Adjuvant Tamoxifen for Male Breast Cancer (MBC). British Journal of Cancer, 65, 252-254. http://dx.doi.org/10.1038/bjc.1992.50

[132] Wang-Rodriguez, J., Cross, K., Gallagher, S., Djahanban, M., Armstrong, J.M., Wiedner, N. and Shapiro, D.H. (2002) Male Breast Cancer: Correlation of ER, PR, Ki-67, HER2/Neu and P53 with Treatment and Survival, a Study of 65 Cases. Modern Pathology, 15, 853-861. http://dx.doi.org/10.1097/01.MP.0000022251.61944.1D

[133] Pich, A., Margaria, E., Chiusa, L., Candelaresi, G. and Dal Canton, O. (1999) Androgen Receptor Expression in Male Breast Carcinoma: Lack of Clinicopathological Association. British Journal of Cancer, 79, 959-964. http://dx.doi.org/10.1038/sj.bjc.6690153

[134] Pich, A., Margaria, E. and Chiusa, L. (1994) Proliferative Activity Is a Significant Prognostic Factor in Male Breast Carcinoma. American Journal of Pathology, 145, 481-489.

[135] Xu, S., Yang, Y., Tao, W., Song, Y., Chen, Y., Ren, Y., Liu, J. and Pang, D. (2012) Tamoxifen Adherence and Its Relationship to Mortality in 116 Men with Breast Cancer. Breast Cancer Research and Treatment, 136, 495-502. http://dx.doi.org/10.1007/s10549-012-2286-z

[136] Anelli, T.F., Anelli, A., Tran, K.N., Lebwohl, D.E. and Borgen, P.I. (1994) Tamoxifen Administration Is Associated with a High Rate of Treatment-Limiting Symptoms in Male Breast Cancer Patients. Cancer, 74, 74-77. http://dx.doi.org/10.1002/1097-0142(19940701)74:1<74::AID-CNCR2820740113>3.0.CO;2-\#

[137] Pemmaraju, N., Munsell, M.F., Hortobagyi, G.N. and Giordano, S.H. (2012) Retrospective Review of Male Breast Cancer Patients: Analysis of Tamoxifen-Related Side-Effects. Annals of Oncology, 23, 1471-1474. http://dx.doi.org/10.1093/annonc/mdr459

[138] Visram, H., Kanji, F. and Dent, S.F. (2010) Endocrine Therapy for Male Breast Cancer: Rates of Toxicity and Adherence. Current Oncology, 17, 17-21.

[139] Miao, H., Verkooijen, H.M., Chia, K.S., Bouchardy, C., Pukkala, E., Larønningen, S., Mellemkjær, L., Czene, K. and Hartman, M. (2011) Incidence and Outcome of Male Breast Cancer: An International Population-Based Study. Journal of Clinical Oncology, 29, 4381-4386. http://dx.doi.org/10.1200/JCO.2011.36.8902

[140] Hayes, T.G. (2009) Pharmacologic Treatment of Male Breast Cancer. Expert Opinion on Pharmacotherapy, 10, 24992510. http://dx.doi.org/10.1517/14656560903200634

[141] Nordman, I.C. and Dalley, D.N. (2008) Breast Cancer in Men: Should Aromatase Inhibitors Become First-Line Hormonal Treatment? Breast Journal, 14, 562-569. http://dx.doi.org/10.1111/j.1524-4741.2008.00648.x

[142] Hayes, T. (2002) Pharmacotherapy for Male Breast Cancer. Expert Opinion on Pharmacotherapy, 3, 701-708. http://dx.doi.org/10.1517/14656566.3.6.701

[143] White, J., Kearins, O., Dodwell, D., Horgan, K., Hanby, A.M. and Speirs, V. (2011) Male Breast Carcinoma: Increased Awareness Needed. Breast Cancer Research, 13, 219. http://dx.doi.org/10.1186/bcr2930

[144] Doyen, J., Italiano, A., Largillier, R., Ferrero, J.M., Fontana, X. and Thyss, A. (2010) Aromatase Inhibition in Male Breast Cancer Patients: Biological and Clinical Implications. Annals of Oncology, 21, 1243-1245. http://dx.doi.org/10.1093/annonc/mdp450

[145] Eggemann, H., Ignatov, A., Smith, B.J., Altmann, U., von Minckwitz, G., Röhl, F.W., Jahn, M. and Costa, S.D. (2013) Adjuvant Therapy with Tamoxifen Compared to Aromatase Inhibitors for 257 Male Breast Cancer Patients. Breast Cancer Research and Treatment, 137, 465-470. http://dx.doi.org/10.1007/s10549-012-2355-3

[146] Nahleh, Z.A. (2006) Hormonal Therapy for Male Breast Cancer: A Different Approach for a Different Disease. Cancer Treatment Reviews, 32, 101-105.

[147] Giordano, S.H. (2005) A Review of the Diagnosis and Management of Male Breast Cancer. Oncologist, 10, $471-479$.

[148] Buzdar, A.U. (2003) Breast Cancer in Men. Oncology (Williston Park), 17, 1361-1364.

[149] Volm, M.D. (2003) Male Breast Cancer. Current Treatment Options in Oncology, 4, 159-164.

[150] Walshe, J.M., Berman, A.W., Vatas, U., Steinberg, S.M., Anderson, W.F., Lippman, M.E. and Swain, S.M. (2007) A Prospective Study of Adjuvant CMF in Males with Node Positive Breast Cancer: 20-Year Follow-Up. Breast Cancer Research and Treatment, 103, 177-183. http://dx.doi.org/10.1007/s10549-006-9363-0

[151] Liu, T., Tong, Z., He, L. and Zhang, L. (2011) Clinicopathological Characteristics and Survival Analysis of 87 Male Breast Cancer Cases. Breast Care (Basel), 6, 446-451. http://dx.doi.org/10.1159/000335204

[152] Sulyok, Z. and Köves, I. (1993) Male Breast Tumors. European Journal of Surgical Oncology, 19, 581-586.

[153] Nahleh, Z. and Girnius, S. (2006) Male Breast Cancer: A Gender Issue. Nature Reviews Clinical Oncology, 3, $428-437$. 
http://dx.doi.org/10.1038/ncponc0564

[154] Wagner, J.L., Thomas Jr., C.R., Koh, W.J. and Rudolph, R.H. (1995) Carcinoma of the Male Breast: Update 1994. Medical and Pediatric Oncology, 24, 123-132. http://dx.doi.org/10.1002/mpo.2950240213

[155] Satram-Hoang, S., Ziogas, A. and Anton-Culver, H. (2007) Risk of Second Primary Cancer in Men with Breast Cancer. Breast Cancer Research, 9, R10.

[156] Hemminki, K., Scélo, G., Boffetta, P., Mellemkjaer, L., Tracey, E., Andersen, A., et al. (2005) Second Primary Malignancies in Patients with Male Breast Cancer. British Journal of Cancer, 92, 1288-1292. http://dx.doi.org/10.1038/sj.bjc.6602505

[157] Auvinen, A., Curtis, R.E. and Ron, E. (2002) Risk of Subsequent Cancer Following Breast Cancer in Men. Journal of the National Cancer Institute, 94, 1330-1332. http://dx.doi.org/10.1093/jnci/94.17.1330

[158] Xia, L.P., Zhou, F.F., Guo, G.F., Wang, F., Wang, X., Yuan, Z.Y. and Zhang, B. (2010) Chinese Female Breast Cancer Patients Show a Better Overall Survival than Their Male Counterparts. Chinese Medical Journal, 123, 2347-2352.

[159] Müller, A.C., Gani, C., Rehm, H.M.E., Eckert, F., Bamberg, M., Hehr, T. and Weinmann, M. (2012) Are There Biologic Differences between Male and Female Breast Cancer Explaining Inferior Outcome of Men Despite Equal Stage and Treatment?! Strahlentherapie und Onkologie, 188, 782-787. http://dx.doi.org/10.1007/s00066-012-0118-z

[160] Anan, K., Mitsuyama, S., Nishihara, K., Abe, Y., Iwashita, T., lhara, T., Tamae, K., Ono, M. and Toyoshima, S. (2004) Breast Cancer in Japanese Men: Does Sex Affect Prognosis? Breast Cancer, 11, 180-186. http://dx.doi.org/10.1007/BF02968299

[161] Borgen, P.I., Senie, R.T., Mckinnon, W.M. and Rosen, P.P. (1997) Carcinoma of the Male Breast: Analysis of Prognosis Compared with Matched Female Patients. Annals of Surgical Oncology, 4, 385-388. http://dx.doi.org/10.1007/BF02305550

[162] Willsher, P.C., Leach, I.H., Ellis, I.O., Bourke, J.B., Blamey, R.W. and Robertson, J.F. (1997) A Comparison of Outcome of Male Breast Cancer with Female Breast Cancer. The American Journal of Surgery, 173,185-188.

[163] Guinee, V.F., Shallenberger, R.C., Olsson, H., Moller, T., van den Blink, J.W., Peter, Z., et al. (1993) The Prognosis of Breast Cancer in Males. A Report of 335 Cases. Cancer, 71, 154. http://dx.doi.org/10.1002/1097-0142(19930101)71:1<154::AID-CNCR2820710125>3.0.CO;2-\#

[164] Rossman, E., Libjegren, A. and Bergh, J. (2007) Male Breast Cancer-How to Treat? Breast Cancer Online, 10, 1-6.

[165] Temmim, L., Luqmani, Y.A., Jarallah, M., Juma, I. and Mathew, M. (2001) Evaluation of Prognostic Factors in Male Breast Cancer. The Breast, 10, 166-175.

[166] Bruce, D.M., Heys, S.D., Payne, S., Miller, I.D. and Eremin, O. (1996) Male Breast Cancer: Clinico-Pathological Features, Immunocytochemical Characteristics and Prognosis. European Journal of Surgical Oncology, 22, 42-46. http://dx.doi.org/10.1016/S0748-7983(96)91418-3

[167] Salvadori, B., Saccozzi, R., Manzari, A., Andreola, S., Conti, R.A., Cusumano, F. and Grassi, M. (1994) Prognosis of Breast Cancer in Males: An Analysis of 170 Cases. European Journal of Cancer, 30, 930-935. http://dx.doi.org/10.1016/0959-8049(94)90117-1

[168] Kardas, I., Seitz, G., Limon, J., Niezabitowski, A., Rys, J., Theisinger, B., Welter, C. and Blin, N. (1993) Retrospective Analysis of Prognostic Significance of the Estrogen-Inducible pS2 Gene in Male Breast Carcinoma. Cancer, 72, 16521656. http://dx.doi.org/10.1002/1097-0142(19930901)72:5<1652::AID-CNCR2820720526>3.0.CO;2-4

[169] Clark, J.L., Nguyen, P.L., Jaszcz, W.B., Jatoi, A. and Niehans, G.A. (2000) Prognostic Variables in Male Breast Cancer. American Surgeon, 66, 502-511.

[170] Foerster, R., Foerster, F.G., Wulff, V., Schubotz, B., Baaske, D., Wolfgarten, M., Kuhn, W.C. and Rudlowski, C. (2011) Matched-Pair Analysis of Patients with Female and Male Breast Cancer: A Comparative Analysis. BMC Cancer, 11, 335. http://dx.doi.org/10.1186/1471-2407-11-335

[171] Avisar, E., McParland, E., Dicostanzo, D. and Axelrod, D. (2006) Prognostic Factors in Node-Negative Male Breast Cancer. Clinical Breast Cancer, 7, 331-335. http://dx.doi.org/10.3816/CBC.2006.n.046

[172] Meattini, I., Livi, L., Franceschini, D., Saieva, C., Scotti, V., Casella, D., et al. (2013) Treatment of Invasive Male Breast Cancer: A 40-Year Single-Institution Experience. La Radiologia Medica, 118, 476-486. http://dx.doi.org/10.1007/s11547-012-0867-X

[173] Arslan, U.Y., Oksuzoglu, B., Ozdemir, N., Aksoy, S., Alkış, N., Gök, A., et al. (2012) Outcome of Non-Metastatic Male Breast Cancer: 118 Patients. Medical Oncology, 29, 554-560. http://dx.doi.org/10.1007/s12032-011-9978-9

[174] Ravi, A., Bang, H., Karsif, K. and Nori, D. (2012) Breast Cancer in Men: Prognostic Factors, Treatment Patterns, and Outcome. American Journal of Men's Health, 6, 51-58. http://dx.doi.org/10.1177/1557988311416495

[175] De Ieso, P.B., Potter, A.E., Le, H., Luke, C. and Gowda, R.V. (2012) Male Breast Cancer: A 30-Year Experience in 
South Australia. Asia-Pacific Journal of Clinical Oncology, 8, 187-193. http://dx.doi.org/10.1111/j.1743-7563.2011.01492.x

[176] André, S., Fonseca, I., Pinto, A.E., Cardoso, P., Pereira, T. and Soares, J. (2001) Male Breast Cancer? A Reappraisal of Clinical and Biologic Indicators of Prognosis. Acta Oncologica, 40, 472-478.

[177] Herman, K., Lobaziewicz, W., Skotnicki, P., Fortuna, J., Kusy, T. and Leśniak, T. (2000) Male Breast Cancer. Does the Prognosis Differ Compared to Female? Neoplasma, 47, 191-195.

[178] de Perrot, M. and Deléaval, J. (2000) Thirty-Year Experience of Surgery for Breast Carcinoma in Men. European Journal of Surgery, 166, 929-931. http://dx.doi.org/10.1080/110241500447074

[179] Marchal, F., Salou, M., Marchal, C., Lesur, A. and Desandes, E. (2009) Men with Breast Cancer Have Same DiseaseSpecific and Even-Free Survival as Woman. Annals of Surgical Oncology, 16, 972-978. http://dx.doi.org/10.1245/s10434-009-0327-6

[180] Dabakuyo, T.S., Dialla, O., Gentil, J., Poillot, M.L., Roignot, P., Cuisenier, J. and Arveux, P. (2012) Breast Cancer in Men in Cote d'Or (France): Epidemiological Characteristics, Treatments and Prognostic Factors. European Journal of Cancer Care, 21, 809-816. http://dx.doi.org/10.1111/j.1365-2354.2012.01365.x

[181] Thalib, L. and Hall, P. (2009) Survival of Male Breast Cancer Patients: Population-Based Cohort Study. Cancer Science, 100, 292-295. http://dx.doi.org/10.1111/j.1349-7006.2008.01032.x

[182] Ulutin, C., Güden, M., Sürenkök, S. and Pak, Y. (1998) Fifteen Cases of Male Breast Carcinoma Treated between 1980 and 1995. Radiation Medicine, 16, 383-386.

[183] Engin, K. and Unsal, M. (1993) Cancer of the Male Breast: The Turkish Experience. Journal of Surgical Oncology, 53, 128-132. http://dx.doi.org/10.1002/jso.2930530216

[184] Tajima, N., Tsukuma, H. and Oshima, A. (2001) Descriptive Epidemiology of Male Breast Cancer in Osaka, Japan. Journal of Epidemiology, 11, 1-7.

[185] Chung, H.C., Kim, D.L., Koh, E.H., Kim, J.H., Roh, J.K., Min, J.S., Lee, K.S., Yang, W.I., Kim, B.S. and Lee, K.B. (1991) Expression of Prognostic Factors (EGFR, ER) by Immunohistochemical Staining Method in Male Breast Cancer. Yonsei Medical Journal, 32, 126-130.

[186] Park, S., Kim, J.H., Koo, J., Park, B.W. and Sik Lee, K. (2008) Clinicopathological Characteristics of Male Breast Cancer. Yonsei Medical Journal, 49, 978-986. http://dx.doi.org/10.3349/ymj.2008.49.6.978

[187] Liu, D., Xie, G. and Chen, M. (2013) Clinicopathologic Characteristics and Survival of Male Breast Cancer. International Journal of Clinical Oncology, 19(2), 280-287.

[188] Chen, X.Y., Liu, X.D., Zhang, L., Li, S.F., Shi, Y.H. and Tong, Z.S. (2013) Poorer Survival of Male Breast Cancer Compared with Female Breast Cancer Patients May Be Due to Biological Differences. Japanese Journal of Clinical Oncology, 43, 954-963. http://dx.doi.org/10.1093/jjco/hyt116

[189] Baojiang, L., Tingting, L., Gang, L. and Li, Z. (2012) Male Breast Cancer: A Retrospective Study Comparing Survival with Female Breast Cancer. Oncology Letters, 4, 642-646.

[190] Rai, B., Ghoshal, S. and Sharma, S.C. (2005) Breast Cancer in Males: A PGIMER Experience. Journal of Cancer Research and Therapeutics, 1, 31-33.

[191] El-Beshbeshi, W. and Abo-Elnaga, E.M. (2012) Male Breast Cancer: 10-Year Experience at Mansoura University Hospital in Egypt. Cancer Biology \& Medicine, 9, 23-28.

[192] Ahmed, A., Ukwenya, Y., Abdullahi, A. and Muhammad, I. (2012) Management and Outcomes of Male Breast Cancer in Zaria, Nigeria. International Journal of Breast Cancer, 2012, Article ID: 845143.

[193] Ihekwaba, F.N. (1994) Breast Cancer in Men in Black Africa: A Report of 73 Cases. Journal of the Royal College of Surgeons of Edinburgh, 39, 344-347.

[194] Vaizey, C., Burke, M. and Lange, M. (1999) Carcinoma of the Male Breast-A Review of 91 Patients from the Johannesburg Hospital Breast Clinics. South African Journal of Surgery, 37, 6-8.

[195] Kiluk, J.V., Lee, M.C., Park, C.K., Meade, T., Minton, S., Harris, E., Kim, J. and Laronga, C. (2011) Male Breast Cancer: Management and Follow-Up Recommendations. Breast Journal, 17, 503-509. http://dx.doi.org/10.1111/j.1524-4741.2011.01148.x 
Scientific Research Publishing (SCIRP) is one of the largest Open Access journal publishers. It is currently publishing more than 200 open access, online, peer-reviewed journals covering a wide range of academic disciplines. SCIRP serves the worldwide academic communities and contributes to the progress and application of science with its publication.

Other selected journals from SCIRP are listed as below. Submit your manuscript to us via either submit@scirp.org or Online Submission Portal.
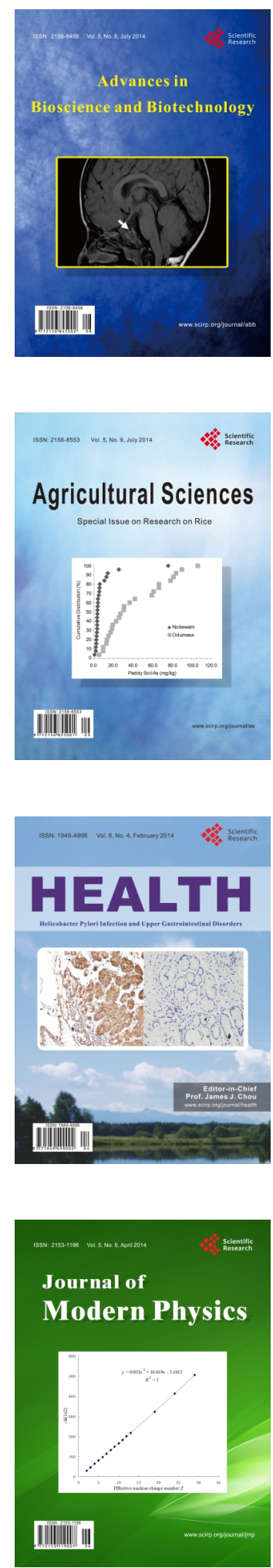
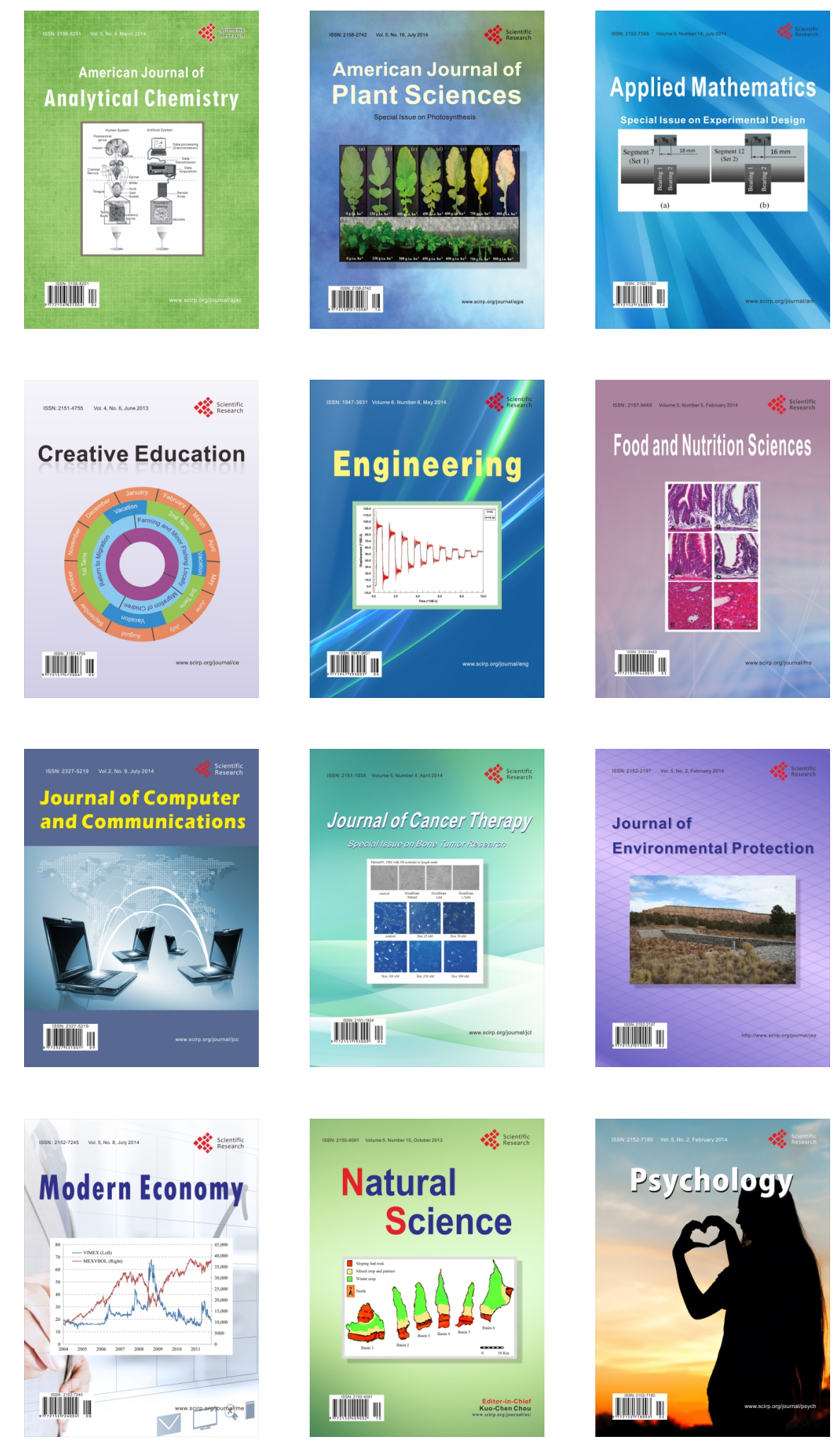